\title{
Towards Climate Change Resilient of Hail Haor, Sylhet: Reviewing the Role of the Co-Management Approach
}

\author{
Monoj Kumar Majumder ${ }^{1}$, Sabuj Kanti Mazumder ${ }^{2}$, Md. Mostafa Monwar ${ }^{3}$ and \\ ${ }^{4}$ Lipi Rani Basak \\ ${ }^{1}$ Lecturer, Department of Agricultural Economics, Sher-e-Bangla Agricultural University, Dhaka,Bangladesh \\ ${ }^{2}$ Assistant Professor, Department of Aquatic Resource Management, Sylhet Agricultural University, Bangladesh \\ ${ }^{3}$ Lecturer, Institute of Marine Sciences and Fisheries, Chittagong University, Bangladesh \\ ${ }^{4}$ Veterinary Surgeon, Ministry of Fisheries and Livestock, Nabigonj, Hobigonj, Bangladesh
}

\begin{abstract}
Hail haor has played a crucial role in the natural fish production, maintenance of biodiversity and creation of employment in the north-east area of Bangladesh. In the recent years it is losing its reputation. Although climate change is the main reason for the adverse impact on its beauty and resources, other factors such as population increase, over exploitation of fish, and lack of knowledge about its economic importance, are also responsible. This study was undertaken to review activities of the existing co-management organizations in the Hail haor in the context of threats of climate change in the locality. The findings show that $57 \%$ of the respondents' main occupation is fishing. The respondent community people show a degree of concern, and perceive the manifestations of climate change as changes in temperature, rainfall and water flow. The two concerned Resource Management Organizations (RMO) are reasonably operational. The Borogangina RMO (score of 80.60) has been found to be better performing as compared to Dumuria (score 66). There remain some problems in the study area which pose a challenge to RMOs members. In this context government should restart the existing comanagement system in the Hail haor for the sustainable development of the haor.
\end{abstract}

Keywords: Hail Haor, RMO, CMO, FGD

\section{Introduction}

Bangladesh is one of the poor countries in the South Asia where most of the people depend on fishes for their nutrition. About $60 \%$ of total demand of protein is fulfilled from fishes. Wetlands, rivers, khals, and estuaries are the major sources of fishes and its highly productive environment support the livelihoods of millions of poor people (Dev 2011). Wetlands in Bangladesh encompass a wide variety of dynamic ecosystems including mangrove forests, natural lakes, man-made reservoirs (such as the Kaptai lake), freshwater marshes, oxbow lakes (baors), beels (big depressions where water remains year long), river, haors (bowl-shaped large tectonic depression and aggregation of many beels, inundated during monsoon season creating a vast sheets of water) and extensive floodplains that are seasonally inundated (Akter 2011). Among the wetlands, haors have a great contribution for natural fish production and bio- diversity that is significant at local, national and regional levels. In Bangladesh, haors are found mainly in grater Sylhet and greater Mymensingh regions (Kazal 2010).

Among the haors, Hail haor of Sylhet is one of the largest and important one. It is located in the north-east region of Bangladesh under Sreemongol upazila of Moulovibazar district, and is typical of deeply flooded basins. The wet season water area of Hail haor is approximately 14,000 ha, whereas the dry season area is typically just over 3,000 ha on an average. Approximately 172,000 people live in 61 villages around the haor. It is considered as a natural fish habitat in the north-east Bangladesh. It is also famous for its rich biodiversity. Surrounding community people depends on this haor for their livelihood.

In the recent years Hail haor has lost its reputation for different reasons. Such factors as water extraction for irrigation, excessive fish harvesting, excessive harvest of other aquatic resources and conversion of these wetlands into rice lands and brick fields are destroying the rich natural productivity and bio-diversity of the Hail haor. Both climate change and other anthropogenic factors such as, population increase, over exploitation of fish, and lack of knowledge of conservation are also responsible for this habitat destruction. To conserve this wetland and restore its biodiversity, the government introduced a co-management system in 1999 with the assistance of USAID through the MACH (Management of Aquatic Ecosystems through Community Husbandry) project. These co-management activities are coordinated by a local institutional structure namely Resource Management Organization (RMO). RMOs serve as a platform for bringing together community people and the government for the natural resource conservation and management. The members of RMOs are working towards the sustainable development of this haor with the help of local community.

As the production of natural fisheries, the sustainable development of the natural resources and the overall socio-economic development and livelihood of local people of this area are highly dependent on this 
haor, hence it is necessary to review the effectives of the existing co-management systems for resilient climate change impact. Borrini-Feyerabend et al. (2004) defined co-management as 'a situation in which two or more social actors negotiate, define and guarantee amongst themselves a fair sharing of the management functions, entitlements, and responsibilities for a given territory, area or set of natural resources'. In fisheries context, comanagement is defined as 'a management arrangement whereby government and user groups share responsibility for managing and utilizing fishery resources with the goal of achieving a balance between economic and social goals, and within a framework of preserving ecosystem and fishery resources.

This study was undertaken to review activities of the existing co-management organizations to resilient climate change. The specific objectives were as follows:

- Review the existing socio-demographic status of the respondent community members in the study area.

- Identify the major manifestations and implications of climate change as experienced by the community.

- Review the nature and status of existing co-management system of Hail haor.

- Suggest an appropriate strategy for improving co-management approach to conserve Hail haor as a climate resilience ecosystem.

\subsection{Study area:}

\section{Material And Methods}

Hail haor was selected for this study because it is one of the largest and most important haors in Bangladesh. It is situated in the Sreemongal upazila under Moulavibazar district. Among the RMOs, Borogangina and Dumuria RMOs were selected for the study because of their economic importance and location. Description of the study area (Hail haor) is given in Table 1.

Table 1. Salient features of the Hail haor, Sylhet, Bangladesh

\begin{tabular}{|l|l|}
\hline Area & $\begin{array}{l}\text { Wet season: } 14,000 \text { ha (appx.) } \\
\text { Dry season: } 4,000 \text { ha (appx.) }\end{array}$ \\
\hline Location & $\begin{array}{l}\text { It is in the anticline between the Balishara and Barshijura hills to the east and the Satgaon } \\
\text { hills to the west. }\end{array}$ \\
\hline Geography & $\begin{array}{l}\text { The basin water originates from the surrounding hills, approximately } 85 \% \text { of the catchment } \\
\text { lies in Bangladesh and } 15 \% \text { in India. }\end{array}$ \\
\hline Coordinates & $\begin{array}{l}\text { Latitude: } 24^{\circ} 25^{\prime} 33^{\prime \prime} \mathrm{N} \text { and } \\
\text { Longitude: } 91^{\circ} 40^{\prime} 57^{\prime \prime} \mathrm{E}\end{array}$ \\
\hline Village & 28 nos. \\
\hline Households & 9448 (appx.) \\
\hline Population & 59,852 (appx.) \\
\hline Main occupation & Fishing \\
\hline Covered union & 7 nos. \\
\hline Covered upazila & 2 (Sreemongol and Moulavi Bazar sadar) \\
\hline $\begin{array}{l}\text { Number and name of the } \\
\text { RMOs }\end{array}$ & 8 (Agari, Ramedia, Borogangina, Dumuria, Jethua, Kajura, Balla and Sananda) \\
\hline Total general body members & 426 (Male 317, Female 109) \\
\hline Total executive members & 122 (Male 95, Female30) \\
\hline Total water body under RMOs & 21 nos. \\
\hline Total Sanctuaries & 14 nos. (including Baikka beel) \\
\hline
\end{tabular}

Source: Quarterly Fact sheet, Dec 11-Feb 12, IPAC office, Sreemongal, Sylhet.

\subsection{Methodology}

Data were collected from the related respondents of the selected area and analyzed according to the objectives set for the study. Field level primary data were collected through direct interviews, focus group discussions (FGDs) and key informant interviews. A total of 20 direct interviews were taken from the community people during 20-21 October, 2012 and FGDs on 8 November, 2012 in the Baikka beel watch tower and Hazipur Bazar with a pre-structured questionnaire. Before taking interview, the purpose of the study have been explained clearly and made clear to the respondents in order to collect relevant information (Khan 2003). Field data were collected from different types of respondents including RMO members, fisheries resources user group (FRUG) members, community people, and relevant officials. Secondary data were also collected from local Integrated Protected Area Co-management (IPAC) office, weather office and Borogangina RMO office. The collected data were coded, summarized and processed for analysis. To avoid possible errors and inconsistencies the collected data were verified. Then all the collected data were summarized and scrutinized carefully. Data entry and analysis were done by using the Microsoft Excel software.

Score diagram matrixes have been calculated through five major indicators. Five major indicators have five subindicators each with some further specifications. Questions were asked on the basis of sub-indicators and scored 
on the basis of indicator particulars (see Appendix). For presenting the findings both descriptive and graphical analyses were used.

\subsection{Socio-demographic characteristics of the respondents}

\section{Results And Discussion}

Among the respondents about $51 \%$ were fishers (who were members of FRUG), about $23 \%$ were RMO members, $20 \%$ were community people, and about $6 \%$ were officials (Table 2 ).

Table 2. Classification of the respondents $(\mathrm{N}=35)$

\begin{tabular}{|c|l|c|}
\hline Sl. No & Types of the respondent & No. of the respondents and (\%) \\
\hline 1 & Member of the RMOs & $8(23)$ \\
\hline 2 & Member of the FRUGs & $20(57)$ \\
\hline 3 & Community people & $5(14)$ \\
\hline 4 & Official person & $2(6)$ \\
\hline \multicolumn{2}{|r|}{ Total $=$} & $\mathbf{3 5 ( 1 0 0 )}$ \\
\hline
\end{tabular}

Age is a crucial characteristic of the social science research because normally we think that if person is more aged, he is more experienced, but a combination of different aged experienced is necessary in social science research. In this study the respondents represented all age groups (Fig. 1). Majority of the respondents (57\%) were in the range of $40-50$ years. $23 \%$ were within $30-40$ years of age.

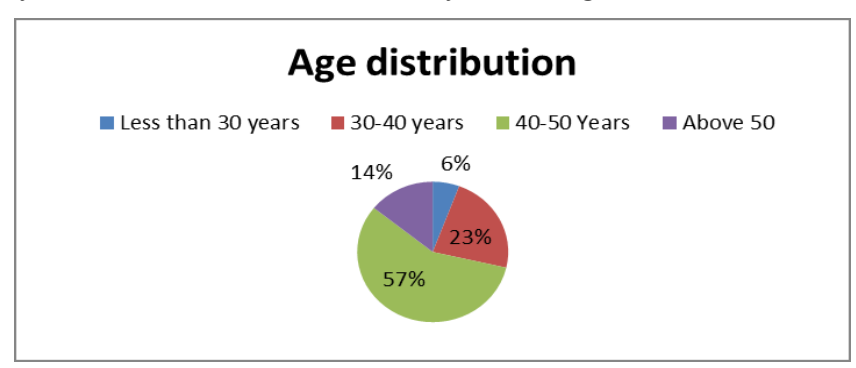

Figure 1. Age distribution of the respondents.

Educational status of the respondents showed a normal distribution, with most of the respondents having completed primary and secondary school level. Among the six categories, the category with the most respondents was education up to class eight (Table 3). 'Higher School Certificate and above' had the lowest percentage (8.57), similarly the category of 'illiterate' also accounted for the same percentage (8.57).

Table 3: Educational levels of the respondents.

\begin{tabular}{|c|l|c|}
\hline Sl. No. & \multicolumn{1}{|c|}{ Qualification } & Number (\%) \\
\hline 1 & Higher Secondary Certificate (HSC) and above & $3(8.57)$ \\
\hline 2 & Secondary School Certificate (SSC) & $5(14.29)$ \\
\hline 3 & Completed class eight level & $7(20)$ \\
\hline 4 & Completed primary level & $11(31.43)$ \\
\hline 5 & Can sign only & $6(17.14)$ \\
\hline 6 & Illiterate & $3(8.57)$ \\
\hline
\end{tabular}

Occupation is a very important socio-demographic characteristic in the locality, because social status and living standard are intricately linked to occupation. Among the respondents, fishing, business, service and agriculture were the main occupational categories (Fig. 2). Fishing constituted the main occupation in the study area (about $57 \%)$.

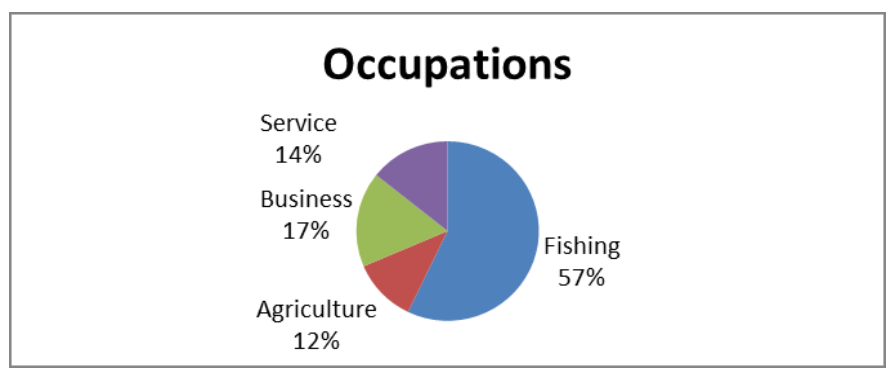

Figure 2. Major occupations of the respondents. 


\subsection{Perception of climate change by the community people}

The respondent community people are not well conversed with the term of 'climate change' as a whole because they are not much educated and have little access to the media. They however feel that something is happening in their environment. The community people are concerned about different manifestations of the climate, e.g. temperature rise, rainfall changes, and disasters. The respondents' concern and cognizance about some selected manifestations of the local climatic conditions are depicted in Table 4. All the rspondents were concerned about the temparature increase, rainfall changes, water flow decrease of the haor, and frequent natural disasters in the locality, and about $62.86 \%$ were concerned about siltation. A good number of respondents were not adequately familiar with the term 'biodiversity'.

Table 4. Level of concern and cognizance of the respondent community members regarding selected manifestations of climate change $(\mathrm{N}=35)$.

\begin{tabular}{|c|l|c|c|c|c|}
\hline \multirow{2}{*}{$\begin{array}{c}\text { Sl. } \\
\text { No. }\end{array}$} & Manifestations & \multicolumn{4}{|c|}{ Concern and cognizance } \\
\cline { 3 - 6 } & & $\begin{array}{c}\text { Number } \\
\text { (Yes) }\end{array}$ & Percentage & Number & Percentage \\
\hline 1 & Temperature increase & 35 & 100 & 0 & 0 \\
\hline 2 & Rainfall changes & 35 & 100 & 0 & 0 \\
\hline 3 & Water flow decrease & 35 & 100 & 0 & 0 \\
\hline 4 & Siltation increase & 22 & 62.86 & 13 & 37.14 \\
\hline 5 & Biodiversity loss & 15 & 42.86 & 20 & 57.14 \\
\hline 6 & Frequent natural disasters & 35 & 100 & 0 & \\
\hline 7 & $\begin{array}{l}\text { Vectors (mosquito-borne infections, } \\
\text { insects) increase }\end{array}$ & 12 & 34.28 & 23 & \\
\end{tabular}

Most respondents perceived that the environment around them has been changing (Table 5).

Table 5: Respondent community members' perception about changes in selected climatic factors.

\begin{tabular}{|c|l|c|c|c|}
\hline Sl. No. & Manifestations & \multicolumn{3}{|c|}{ Perception } \\
\cline { 3 - 4 } & & Number (increase) & Number (decrease) & $\begin{array}{c}\text { Number (No } \\
\text { change) }\end{array}$ \\
\hline 1 & Temperature increase & $35(100 \%)$ & 0 \\
\hline 2 & Rainfall changes & $12(34.28 \%)$ & $23(65.71)$ & 0 \\
\hline 3 & Water flow decrease & 0 & $35(100)$ & 0 \\
\hline 4 & Siltation increase & $22(62.86 \%)$ & $7(20)$ & $20(57.14)$ \\
\hline 5 & Biodiversity loss & $18(51.43 \%)$ & $12(34.29)$ & $5(14.29)$ \\
\hline 6 & Frequent natural disasters & $11(31.43 \%)$ & $3(8.57)$ & $21(60)$ \\
\hline 7 & $\begin{array}{l}\text { Vectors (mosquito-borne infections, } \\
\text { insects) increase }\end{array}$ & & \\
\hline
\end{tabular}

About 34\% respondents perceived that rainfall is increasing whereas $66 \%$ said it is decreasing. $100 \%$ respondents perceived that temperature is increasing and water flow is decreasing. Again, $22 \%$ respondents experienced that biodiversity is increasing though $57 \%$ said they have no idea about it. $51 \%$ opined that natural disasters are on the increase, while $34 \%$ argued that it is decreasing. $60 \%$ respondents have no perception about vectors. About $63 \%$ respondents said that they have no idea of the term 'climate change'.

Table 6. The Pattern of changes in selected climatic factors as reported in the government document

\begin{tabular}{|l|c|c|c|c|c|c|c|c|c|}
\hline Parameters & 2003 & 2004 & 2005 & 2006 & 2007 & 2008 & 2009 & 2010 & 2011 \\
\hline Temperature $\left({ }^{\circ} \mathrm{C}\right)$ & 24.79 & 24.88 & 25.23 & 25.57 & 24.72 & 25.48 & 25.46 & 25.51 & 25.01 \\
\hline Rainfall $(\mathrm{cm})$ & 180.5 & 317.5 & 201.17 & 162.67 & 224.33 & 180.75 & 197.25 & 187.67 & 171.25 \\
\hline
\end{tabular}

Source: Meteriological office, Sreemongol.

From Table 6, it is evident that average temperature is increasing in the study area and the average rainfall is decreasing which is similar with the local community people's perception. Even though temperature slightly fluctuated, rainfall is decreasing over the years.

Linear trend line of averaged mean temperature during period 1978-2007 showed that temperature has risen by $0.9^{\circ} \mathrm{C}$ and rainfall is characterized by large inter-annual variability with substantial decrease in the amount over the years from 2002 to 2006 (Bhusal 2009). The analysis reflects that $90 \%$ respondents perceive the temperature has increased and $97 \%$ said that they are experiencing unpredictable rainfall patterns since last 10 years

\subsection{Nature and status of existing co-management system of Hail haor}

The purpose of the RMOs was to provide sustainable production and livelihood for the beneficiaries by establishing environmental congenial improved and durable management of water bodies through direct 
engagement of beneficiaries and resource consuming peoples of that area and to improve the quality of life of people of inhabited areas by adopting various development oriented programs.

Co-management system is a situation where community people who use the resources are engaged in the management system with the government. The government promotes co-management for attaining some goals such as, increased fish production, enhanced biodiversity and its conservation and enhanced employment and livelihood. Like other wetlands, Hail haor is also managed by this co-management system namely, RMOs. There are eight RMOs under the Hail haor. Among these organizations, two RMOs namely, Borogangina and Dumuria RMOs were considered for this study. These organizations are managed by written constitution. To analyze the nature of RMOs activities such as purpose, governance structure, etc. activities of these two organizations were compared (Table 7) vis-à-vis their constitution for measuring the nature of RMOs.

Table 7. Comparison of the nature of RMOs with its constitution.

\begin{tabular}{|c|c|c|}
\hline According to constitution & Borogangina RMO & Dumuria RMO \\
\hline \multicolumn{3}{|l|}{ General structure of the organization } \\
\hline $\begin{array}{l}\text { Executive committee: There is an executive committee } \\
\text { containing } 11 \text { members for running the activities of RMO. } \\
\text { Executive Committee members are elected by the general } \\
\text { members of the organization through ballot paper for two (2) } \\
\text { years. }\end{array}$ & Follow their constitution & As per constitution \\
\hline $\begin{array}{l}\text { General committee: General committee contains } 51 \\
\text { members. }\end{array}$ & According to the constitution & $\begin{array}{l}\text { Follow the } \\
\text { constitution }\end{array}$ \\
\hline \multicolumn{3}{|l|}{ Activities of the organization } \\
\hline $\begin{array}{l}\text { Monitoring the condition of wetland and change of its } \\
\text { nature }\end{array}$ & $\begin{array}{l}\text { Continuous monitoring for } \\
\text { increasing fish production }\end{array}$ & $\begin{array}{l}\text { Monitoring but not in } \\
\text { a continuous basis }\end{array}$ \\
\hline $\begin{array}{ll}\text { 2. Raise awareness about resource and environment of } \\
\text { wetlands }\end{array}$ & Discuss in every meeting. & $\begin{array}{l}\text { Discuss in every } \\
\text { meeting. }\end{array}$ \\
\hline $\begin{array}{l}\text { Ensure the participation of poor fishers along with local } \\
\text { community to stipulate plan, implement and preserve. }\end{array}$ & $\begin{array}{l}60 \% \text { members of the general } \\
\text { committee are poor fishers }\end{array}$ & $\begin{array}{l}60 \% \text { members of the } \\
\text { general committee are } \\
\text { poor fishers }\end{array}$ \\
\hline $\begin{array}{l}\text { Increase water holding capacity through re-excavation } \\
\text { of khals and beels to facilitate movement of fishes and } \\
\text { improve the habitat of fishes with other flora and } \\
\text { fauna. }\end{array}$ & $\begin{array}{l}\text { Excavate Baikka beel } \\
\text { regularly }\end{array}$ & $\begin{array}{l}\text { Excavate but not in a } \\
\text { regular basis }\end{array}$ \\
\hline $\begin{array}{ll}\text { 5. } & \text { Establish seasonal sanctuary for increasing fish } \\
\text { productivity and other flora and fauna during dry } \\
\text { season. }\end{array}$ & $\begin{array}{l}\text { It is now a permanent } \\
\text { sanctuary where fish catches } \\
\text { are permanently prohibited. }\end{array}$ & No seasonal sanctuary \\
\hline $\begin{array}{l}\text { Forestation for the purpose of environmental } \\
\text { advancement and conservation. }\end{array}$ & $\begin{array}{l}\text { About } 20-25 \text { thousand } \\
\text { "Hijol" trees were planted in } \\
\text { this beel. }\end{array}$ & $\begin{array}{l}\text { Tree plantation and } \\
\text { awareness creation } \\
\text { about forestation is } \\
\text { done. }\end{array}$ \\
\hline Proper utilization of water during lean season & No programs & No programs \\
\hline $\begin{array}{l}\text { 8. Adopt and implement programs regarding } \\
\text { conservation, improvement and durable management } \\
\text { of other resources of wetlands. }\end{array}$ & $\begin{array}{l}\text { Taking many programs for } \\
\text { the sustainable development } \\
\text { of this wetland such as } \\
\text { creating awareness through } \\
\text { different meetings, posters, } \\
\text { festoons, etc. Helping } \\
\text { community people to search } \\
\text { alternative employment, } \\
\text { appoint guards, manage loan } \\
\text { from different organizations } \\
\text { for the poor, etc. }\end{array}$ & $\begin{array}{l}\text { They also take some } \\
\text { similar programs. }\end{array}$ \\
\hline $\begin{array}{l}\text { 9. Adopt and implement programs for socio-economic } \\
\text { improvement of resource users. }\end{array}$ & $\begin{array}{l}\text { Create awareness about } \\
\text { sanitation, education, } \\
\text { negative effects of early } \\
\text { marriage, etc. through } \\
\text { meetings. }\end{array}$ & $\begin{array}{l}\text { Create awareness } \\
\text { about sanitation, } \\
\text { education, etc. } \\
\text { through meetings. }\end{array}$ \\
\hline $\begin{array}{l}\text { 10. Arrange various human resource development programs } \\
\text { like, adult literacy, health education and awareness } \\
\text { building programmes, loan disbursement and vocational } \\
\text { training. }\end{array}$ & No programs & No programs \\
\hline
\end{tabular}

Table 7 reflects that both Borogangina and Dumuria RMO are performing according to their constitution. The main activities of the RMOs including creating awareness, forestation, and monitoring. These are important for achieving the sustainable development of the Hail haor in the face of climate change impact.

A conceptual framework was developed for capacity assessment of RMOs in resource management aiming to develop resilience in the face of climate change implications for the concerned wetlands. This framework is depicted in a matrix format (Table 8). This assessment is participatory, whereby respondents (mainly RMOs member and the officials) opine(s) on a set of indicators (related to soundness of the concerned institution and 
its activities) and assign(s) value to each indicator based on his own judgments. Average of the scores shows the status of the institution.

Table 8. Status of existing management system of Hail haor.

\begin{tabular}{|c|c|c|c|c|c|}
\hline \multirow[t]{2}{*}{ Sl. No. } & \multirow[t]{2}{*}{ Indicators } & \multicolumn{2}{|c|}{ Borogangina RMO } & \multicolumn{2}{|c|}{ Dumuria RMO } \\
\hline & & Point & Percentage & Point & Percentage \\
\hline 1 & Resource management & 8 & \multirow{6}{*}{80.6} & 6 & \multirow{6}{*}{66.0} \\
\hline 2 & Pro-poor & 7.71 & & 7.33 & \\
\hline 3 & Women's role & 6 & & 6 & \\
\hline 4 & Organization/institution & 9.28 & & 7.33 & \\
\hline 5 & Governance and leadership & 9.43 & & 6.33 & \\
\hline & Total point & 40.43 & & 33.0 & \\
\hline
\end{tabular}

Scores were calculated on five broad indicators, namely, 'resource management', 'pro-poor', 'women's role', 'organization/institution', 'governance and leadership'. Borogangina RMO scored 40.43 and Dumuria RMO scored 33.0 out of 50 (Table 8). In percentage Borogangina RMO got 80.6\%, while Dumuria RMO got $66.0 \%$. Indicative scores revealed that Borogangina RMO is performing 'very well', and it may be sustainable; and Dumuria RMO just performs 'satisfactorily'. Among the five indicators 'governance and leadership' scored highest (9.43) and 'women role' scored lowest (6) in Borogangina RMO (Table 8). On the other hand, 'propoor' and 'institution' scored highest (7.33), while 'resource management' and 'women's role' scored lowest (6) in Dumuria RMO (Table 8).

\subsection{Major problems and challenges of co-management system}

During the data collection, several problems and challenges faced (from respondents view and factual observation) by the RMOs have been identified - as noted below:.

1. The co-management system started in 1999 under the Management of Aquatic Ecosystems through Community Husbandry (MACH) project. The agreement was to renew this system after every five years. Various relevant government agencies such as the Department of Land, Department of Fisheries and Department of Livestock were actively involved in the initiative. But after 2010; the government cancelled this agreement and did not renew the tenure of this lease especially for beels which were above 20 acres in size. These beels were handed over to the private sector for aquaculture. The RMOs eventually appealed to the High Court with a writ petition against this decision, and it is still in the process of review. As a result, the management system cannot function properly and faces conflict between community people and the lessee. Besides, the haor is losing its biodiversity due to lack of proper management right.

2. The cost of the writ appeal are being borne by the members of RMOs, which a burden on them

3. The government does not provide any financial help to these RMOs and there is no supportive project in operation now.

4. No alternative income generating sources and loan are available to the poor fishers.

5. The government officials often do not monitor properly.

6. Members of both committees give service voluntarily, so they give time after finishing their own works.

7. After establishment of the permanent fish sanctuary many poor fishers changed their occupation, and as the RMOs do not have any provision for credit or loan for the members, they arranged loan in higher interest rates from the private money lenders.

8. No formal training programmes are conducted about management or natural resources.

\section{Conclusion And Recommendations}

Based on the findings and observations two major categories of recommendations are made which are as follows:

\subsection{Functional recommendations:}

i. More intensive awareness raising campaign should be administered amongst the community people about the importance of natural resources that have direct impact on their livelihood.

ii. More targeted training should be arranged about the better management system and the importance of natural resources.

iii. Micro-credits at easy terms and conditions to the poor fishers for alternative income generating activities may be seriously considered.

\subsection{Policy recommendations.}

i. With the initiation of co-management practice the Hail haor, there were visible improvements. Natural fish production increased rapidly and the socio-economic conditions were also increasing. But after the cancellation of this co-management agreement, Hail haor is rapidly losing its natural fishes and 
biodiversity. In this circumstance, the government should resume co-management for the sustainable development of this wetland and the associated community.

ii. Such co-management practice should preferably be continued on a long-term basis -, at least for 10 years.

iii. The government should allocate money for the maintenance and development of this wetland.

\section{References}

[1]. Akter, A. 2011. People's Perception of environmntal pollution in Mokosh beel, Bangladesh. In: Fox J., Mustafa M.G., Quazi S.A., Miles W.B., Cunningham E.J. and Chassels M. (eds.) Rural livelihoods and protected landscapes: co-management in the wetlands and forests of Bangladesh, IPAC Project, Departments of Forests, Environment and Fisheries, Dhaka, pp.85-98.

[2]. Bhusal, Y.R. 2009. Local peoples' perceptions on climate change, its impacts and adaptation measures in mid-mountain region of Nepal (A case study from Kaski district). Thesis Submitted to the Tribhubhan University for the B.Sc. in Forestry, Institute of Forestry, Pokhara, Nepal.

[3]. Borrini-Feyerabend, M., Pimbert, M.T., Faarvar, A., Kothari and Renard, Y. 2004. Sharing power: learning by doing in comanagement on natural resources throughout the world, IIED and IUCN/ CEESP, Cenesta publication., Tehran, Iran.

[4]. Dev, B. K. 2011. Co-management participation, livelihood, and status among fishers in Baikka beel, Bangladesh'. In: Fox J., Mustafa M.G., Quazi S.A., Miles W.B., Cunningham E.J., and Chassels M. (eds.) Rural livelihoods and protected landscapes: co-management in the wetlands and forests of Bangladesh, IPAC Project, Department of Forests, Environment and Fisheries, Dhaka, pp.66-84.

[5]. Kazal, M. M. H. 2010. Food security strategies of the people living in Haor areas: status and prospects, American International University, Dhaka, Bangladesh.

[6]. Khan, M. A. R. 2003. Performance of LLP and STW under farmer managed irrigation systems in Netrokona district of Bangladesh, M.Sc. Thesis submitted for Agr., Econ., Bangladesh Agricultural University, Mymensingh.

\section{Appendices}

Selected Information about the effectiveness of the RMO in Boro Gangina /Agari

\begin{tabular}{|c|c|c|c|}
\hline Sl.No & Indicators & Indicator particulars & Scores \\
\hline A. & Resource management & & 10 points \\
\hline 1 & $\begin{array}{l}\text { Date of last Annual Development } \\
\text { Plan by addressing climate change }\end{array}$ & Date: & $\begin{array}{l}\text { If the ADP considers climate change } \\
\text { issues }=>2 \\
\text { If there is an ADP and } C C \text { is not } \\
\text { addressed }=>1 \\
\text { No ADP }=>0\end{array}$ \\
\hline 3 & $\begin{array}{l}\text { Change in fish catches of this year as } \\
\text { compared with } 2010\end{array}$ & $\%$ change (compared with 2010 ) & $\begin{array}{l}\text { increase }=>2 \\
\text { same }=>1 \\
\text { decrease }=>0\end{array}$ \\
\hline 5 & $\begin{array}{l}\text { No of conflicts since } 2010 \text { over NR } \\
\text { management }\end{array}$ & $\begin{array}{l}\text { Nos. amongst CMO members: } \\
\text { Nos. with outsiders: }\end{array}$ & $\begin{array}{l}\text { No conflict }=>2 \\
\text { Conflict resolution is in process }=>1 \\
\text { No action to resolve conflicts }=>0\end{array}$ \\
\hline B & Pro-poor & 10 points & \\
\hline 1 & $\begin{array}{l}\text { No and \% RMO General Body } \\
\text { members who are poor (own } \leq 50 \\
\text { decimals cultivable land) }\end{array}$ & No. and \%: & $\begin{array}{l}>60 \% \text { poor }=>2 \\
40-59 \% \text { poor }=>1 \\
<40 \text { poor }=>0\end{array}$ \\
\hline 2 & $\begin{array}{l}\text { Access of poors to natural resources } \\
\text { (fish, plants, etc.) harvest from } \\
\text { wetland or buffer/ landscape zone in } \\
\text { compare to } 2010 .\end{array}$ & $\begin{array}{l}\text { Please elaborate is there any progress in } \\
\text { facilitating co-benefits to poor or any } \\
\text { restrictions in resource use compared to } \\
2010\end{array}$ & $\begin{array}{l}\text { Improved = } 2 \\
\text { Same }=1 \\
\text { Worsen }=0\end{array}$ \\
\hline 3 & $\begin{array}{l}\text { RMO considers vulnerabilities of } \\
\text { poor fishers due to climate change }\end{array}$ & $\begin{array}{l}\text { Cite RMOs initiatives for identification of } \\
\text { vulnerabilities to poor fishers, e.g. focus } \\
\text { group discussions, assessments, and actions } \\
\text { taken to reduce those vulnerabilities }\end{array}$ & $\begin{array}{l}\text { Vulnerability assessments are conducted } \\
\text { and action taken to reduce }=2 \\
\text { Vulnerability assessments done }=1 \\
\text { No special initiative for poor climate } \\
\text { vulnerable poor }=0\end{array}$ \\
\hline 4 & $\begin{array}{l}\text { Returns to people adopting new } \\
\text { enterprises that are environment } \\
\text { friendly promoted by RMO. }\end{array}$ & & $\begin{array}{l}\text { Good } / \text { profitable }=2 \\
\text { OK } / \text { break even }=1 \\
\text { Poor } / \text { loss }=0\end{array}$ \\
\hline 5 & $\begin{array}{l}\text { Impact of RMOs management on } \\
\text { livelihoods of fishers }\end{array}$ & $\begin{array}{l}\text { Through FGDs and discussions, perception } \\
\text { of CMO representatives }\end{array}$ & $\begin{array}{l}\text { Improved }=2 \\
\text { Same }=1 \\
\text { Worse }=0\end{array}$ \\
\hline $\mathbf{C}$ & Women's role & 10 points & \\
\hline 1 & $\%$ of RMOs General Body members & No and \%: & $>=30 \%=>2$ \\
\hline
\end{tabular}


Towards Climate Change Resilient of Hail Haor, Sylhet: Reviewing The Role of The Co-Management

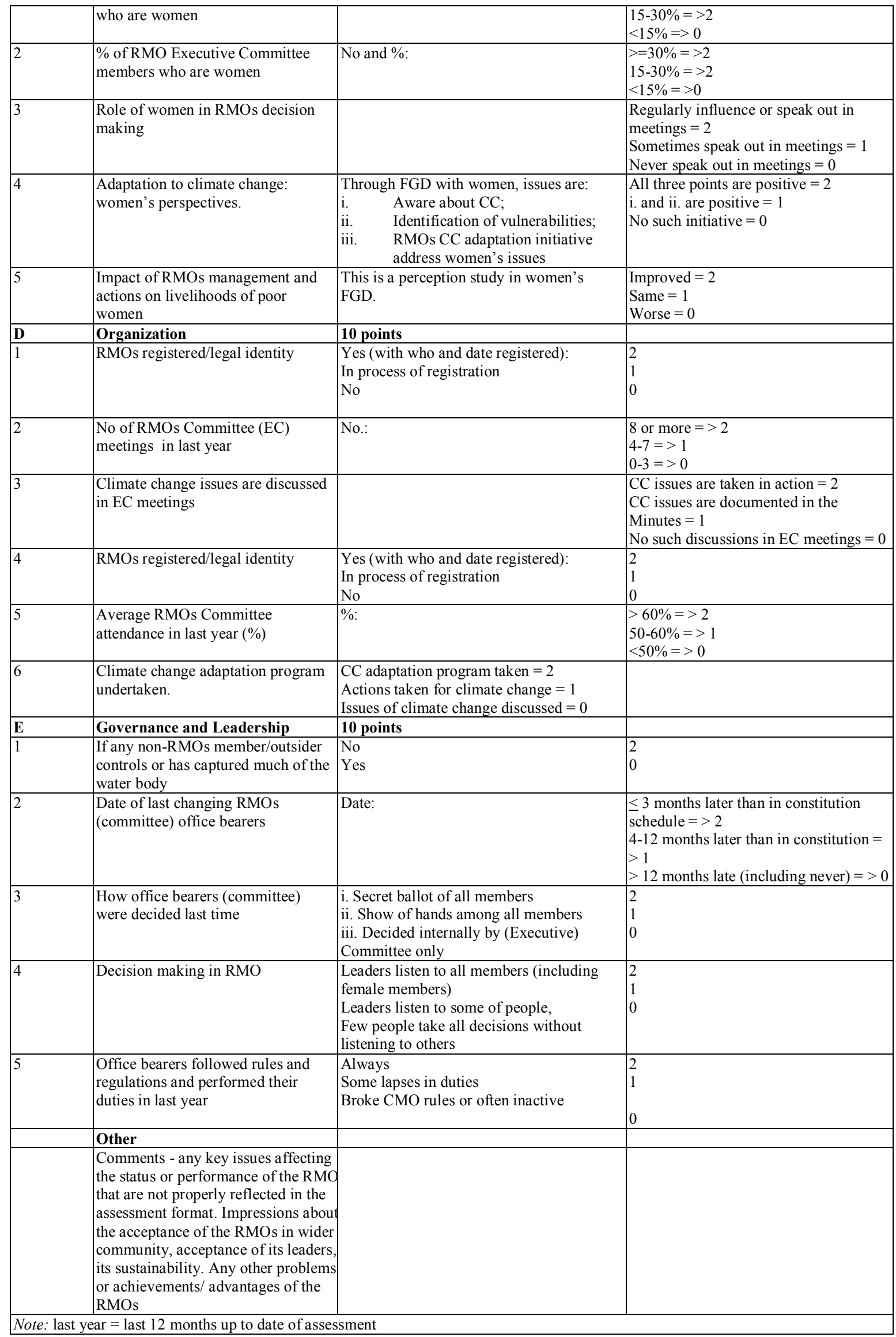

